\title{
Transformation of the endochitinase gene Chi67-1 in Clonostachys rosea 67-1 increases its biocontrol activity against Sclerotinia sclerotiorum
}

\author{
Zhan-Bin Sun ${ }^{\dagger}$, Man-Hong Sun ${ }^{\dagger}$, Mo Zhou and Shi-Dong Li
}

\begin{abstract}
Clonostachys rosea is a promising biocontrol fungus active against various plant fungal pathogens. In this study, the endochitinase-encoding gene Chi67-1, the expression of which is sharply upregulated in C. rosea 67-1 when induced by sclerotia, was transformed into the original isolate by protoplast transformation, and transformants were screened against Sclerotinia rot of soybean. The transformation efficiency was approximately 50 transformants per $1 \times 10^{7}$ protoplasts, and 68 stably heritable recombinants were assayed. The parasitic rates of $32.4 \%$ of the tested strains increased by more than $50 \%$ compared to $43.3 \%$ of the wild type strain in $16 \mathrm{~h}$, and the Rc4-4 transformant showed a parasitic rate of $100 \%$ in $16 \mathrm{~h}$. The control efficiencies of the selected efficient transformants to soybean Sclerotinia stem rot were evaluated in pots in the greenhouse, and the results revealed that Rc4-4 achieved the highest efficiency of $81.4 \%$, which was $31.7 \%$ and $28.7 \%$ higher than the control achieved by the wide type and the pesticide carbendazim, respectively. Furthermore, the expression level of Chi67-1 was 107-fold higher in Rc4-4 than in the wild type, and accordingly, the chitinase activity of the recombinant increased by $140 \%$. The results lay a foundation for the development of efficient genetically engineered strains of $C$. rosea.
\end{abstract}

Keywords: Clonostachys rosea, Endochitinase, Mycoparasitism, Sclerotinia sclerotiorum, Protoplast transformation, Biocontrol agent

\section{Introduction}

Clonostachys rosea (syn. Gliocladium roseum) is a widely distributed mycoparasite of many kinds of plant pathogenic fungi and has shown great potential in controlling plant diseases and promoting crop growth (Cota et al. 2008; Keyser et al. 2016; Morandi et al. 2003; Schöneberg et al. 2015). However, the true potential of this organism is yet to be fully realized, although Prestop, a commercial biocontrol agent (BCA) of $C$. rosea $\mathrm{f}$. catenulate (syn. Gliocladium catenulatum), is currently mass produced and applied to vegetables, herbs and ornamentals in greenhouses and fields (Chatterton and Punja 2009;

\footnotetext{
*Correspondence: sdli@ippcaas.cn

†Zhan-Bin Sun and Man-Hong Sun contributed equally to this work Institute of Plant Protection, Chinese Academy of Agricultural Sciences, No. 2 West Yuanmingyuan Road, Haidian District, Beijing 100193, China
}

Gwynn 2014; Punja and Yip 2003; Rahman and Punja 2007). Thus far, problems such as the unstable efficiency of fungal biopesticides in field applications have limited their development, and the pathogenicity of most wild type isolates needs to be improved to achieve a higher control efficiency.

Several mechanisms are involved in the biocontrol process of $C$. rosea, including mycoparasitism, antagonism, competition for nutrients and space, induction of plant resistance (Lahoz et al. 2004; Papavizas 1985; Rodríguez et al. 2011), and the secretion of a series of cell walldegrading enzymes (Carsolio et al. 1999; Elad and Kapat 1999; Giczey et al. 2001). Of these, extracellular lytic enzymes, especially chitinase, are considered essential for activity against plant pathogens.

Since the 1990s, chitinolytic enzymes from mycoparasites, especially Trichoderma spp., have attracted 
considerable attention due to their antifungal activity, and a series of chitinase-encoding genes that are expressed in media containing chitin or fungal cell wall components have been cloned and functionally analyzed (Carsolio et al. 1994; Lorito et al. 1998; Seidl et al. 2005; Zeilinger et al. 1999). Deletion and interference of the endochitinase-encoding gene affected the biocontrol activity of Trichoderma against fungal pathogens (Romao-Dumaresq et al. 2012; Woo et al. 1999). A number of chitinase-encoding genes were also cloned from $C$. rosea in recent years, and their expressions were found to be intensely stimulated by the plant pathogens Rhizoctonia solani and Fusarium culmorum (Gan et al. 2007; Mamarabadi et al. 2008). Tzelepis et al. (2015) knocked down the endochitinase-encoding gene $\operatorname{chiC} 2$, and found that deletion of chiC2 decreased the inhibitory ability of $C$. rosea against $R$. solani and Botrytis cinerea.

Fungal chitinase has been successfully applied to suppress various soilborne and foliar diseases and improve plant resistance to fungal pathogens (Carsolio et al. 1994; Lorito et al. 1998). Furthermore, transformation of exogenous or homologous genes from Trichoderma also greatly improves the efficiency of biocontrol fungi (Deng et al. 2007; Haran et al. 1993; Limón et al. 1999; MargollesClark et al. 1996; Yang et al. 2011). However, few effective C. rosea strains have been genetically engineered, and the genetic manipulation of antifungal chitinase genes from mycoparasite $C$. rosea is largely unexplored.

Clonostachys rosea strain 67-1 was originally obtained from vegetable soil using a sclerotia baiting method, and this strain exhibits strong biocontrol activity against a range of plant fungal pathogens (Ma et al. 2011; Zhang et al. 2004). Transcriptome sequencing and analysis of 67-1 parasitizing $S$. sclerotiorum sclerotia revealed a remarkable up-regulation of Chi67-1, which encodes a $37 \mathrm{kDa}$ endochitinase. The presence of this gene suggested that Chi67-1 was correlated with mycoparasitism of C. rosea (Sun et al. 2015b). Therefore, in the present study, we investigated the role of this chitinase in mycoparasitism of C. rosea against S. sclerotiorum, and assessed the efficiency of 67-1 transformants overexpressing Chi67-1 against Sclerotinia rot of soybean, with the intention of improving the biocontrol of $C$. rosea.

\section{Materials and methods}

\section{Strains and gene}

Clonostachys rosea 67-1 was originally isolated from a vegetable yard in Ledong farm in Hainan Province, China (Zhang et al. 2004). S. sclerotiorum Ss-H was isolated from Sclerotinia stem rot of soybean in Heilongjiang Province. Both isolates were deposited in the Agricultural Culture Collection of China (strain number: ACCC 39160, ACCC 39161).
Endochitinase gene Chi67-1 (GenBank accession number KT985453) was isolated from C. rosea 67-1 induced by $S$. sclerotiorum sclerotia. The gene encodes a $37 \mathrm{kDa}$ secreted protein with a chitinase-like domain that belongs to group B of glycoside hydrolase family 18 .

\section{Construction of recombinant plasmid}

Plasmid pAN7-1 was used to overexpress the Chi67-1 gene. This plasmid contained a glyceraldehydes-3-phosphate dehydrogenase promoter $(g p d A)$, a terminator $(\operatorname{trp} C)$, a hygromycin B-resistant gene $(h p h)$, and several restriction enzyme cutting sites. The $g p d A$ and $\operatorname{trp} C$ fragments were amplified using the primers $q d z \mathrm{~F} / q d z \mathrm{R}$ and $z z z \mathrm{~F} / z z z \mathrm{R}$, respectively, with a concentration of $10 \mu \mathrm{M}$. The open reading frame (ORF) of Chi67-1 was amplified from the genomic DNA of $C$. rosea 67-1 using the CF and CR primers (Sun et al. 2015c; Table 1).

The recombinant plasmid pAN7-1-Chi67-1 was constructed as follows: pAN7-1 was digested with HindIII, and then ligated together with the fragments $\operatorname{gpdA}$, Chi67-1 ORF and $\operatorname{trpC}$, successively (Fig. 1a) using a pEASY-Uni Seamless Cloning and Assembly Kit (TransGen Biotech, China). Electrophoresis and sequencing were conducted to verify the recombinant plasmid. Afterwards, the plasmid was transferred into $E$. coli DH5 $\alpha$ (Transgen Biotech, Beijing, China) for propagation and extracted for gene transformation.

\section{Protoplast transformation}

Clonostachys rosea 67-1 was incubated on potato dextrose agar (PDA) at $26{ }^{\circ} \mathrm{C}$ for 10 days. Sterile distilled water $(5 \mathrm{~mL})$ was added to the plate and the spores were eluted with a sterile glass spatula and transferred into a 250-mL flask containing PD broth. The fungus was cultured on a fermentation shaker at a speed of $180 \mathrm{rpm}$ at $26^{\circ} \mathrm{C}$. After incubation for $12 \mathrm{~h}$, fresh mycelia were collected using a $125-\mu \mathrm{m}$ sterile sieve, washed five times with sterile distilled water, and rinsed with $0.7 \mathrm{~mol} \mathrm{~L}^{-1}$ of $\mathrm{NaCl}$ to maintain the osmotic pressure. Next, $40 \mathrm{mg} \mathrm{mL}^{-1}$ of snail enzyme (XJK Biotech, Beijing, China) was added to hydrolyze the mycelia, and the culture was incubated in a shaker at $28^{\circ} \mathrm{C}$ at $100 \mathrm{rpm}$ for $3 \mathrm{~h}$. The released protoplasts were filtered through a sterile $0.22-\mu \mathrm{m}$ microfiber filter, and the filtrate was centrifuged at $1500 \times g$ for $10 \mathrm{~min}$. The protoplasts were suspended in STC buffer ( $200 \mathrm{~g}$ of sucrose, $50 \mathrm{~mL}$ of $1 \mathrm{~mol} \mathrm{~L}^{-1}$ Tris$\mathrm{HCl} \mathrm{pH} \mathrm{8.0,} \mathrm{and} 5.55 \mathrm{~g}$ of $\mathrm{CaCl}_{2}$ in $1 \mathrm{~L}$ distilled water) and adjusted to a concentration of $10^{7}$ protoplasts $\mathrm{mL}^{-1}$.

A $100 \mu \mathrm{L}$ suspension of $C$. rosea protoplasts was gently mixed with $20 \mu \mathrm{g}$ of linearized plasmid pAN7-1-Chi67-1 in a $2 \mathrm{~mL}$ Eppendorf tube on ice. After $20 \mathrm{~min}, 1.25 \mathrm{~mL}$ of PTC solution ( $400 \mathrm{~g}$ polyethylene glycol $4000,10 \mathrm{~mL}$ of $1 \mathrm{~mol} \mathrm{~L}^{-1}$ Tris $-\mathrm{HCl} \mathrm{pH} \mathrm{8.0,} \mathrm{and} 20 \mathrm{mg}$ of $\mathrm{CaCl}_{2}$ in $1 \mathrm{~L}$ 
Table 1 Primers used in this study

\begin{tabular}{lll}
\hline Primer & Sequence $\left(\mathbf{5}^{\prime} \mathbf{-} \mathbf{3}^{\prime} \mathbf{)}\right.$ & Purpose \\
\hline ChiF & GTTGTGGTTGCCTGGTG & Real-time PCR \\
ChiR & CCGATACTCTGCTGCTCAT & Hygromycin amplification \\
$h p h F$ & ATGCCTGACTCACCGCGACGTCTG & \\
$h p h R$ & CTATTCCTTTGCCTCGGACGAGTG & Chi67-1 amplification \\
$C F$ & TTCAGAGTAGGCTTTTGGTTGGT & gpdA amplification \\
$C R$ & ACCCCATATTTGCTCATAATCACA & \\
$q d z F$ & ACTCGACCTGCAGGCATGCAAGCTTGAATTCCCTTGTATCTCTACACA & trpC amplification \\
$q d z R$ & ACCAATCCAAAAGCCTACTCTGAAGGGAAAGAAAGAGAAAAGAAAG & \\
$z z z R$ & TGTGATTATGAGCAAATATGGGGGGATCCACTTAACGTTACTGAAA & \\
\hline
\end{tabular}

of distilled water) was added to the transformation system, mixed gently, and incubated at room temperature for $20 \mathrm{~min}$. The mixture was then transferred to TB3 medium ( $3 \mathrm{~g}$ of yeast extract, $3 \mathrm{~g}$ of casein acid hydrolysate, and $200 \mathrm{~g}$ of sucrose in $1 \mathrm{~L}$ of distilled water) and cultivated at $26{ }^{\circ} \mathrm{C}$ at a speed of $100 \mathrm{rpm}$ for $16 \mathrm{~h}$. The transformed protoplasts were harvested by centrifuging the suspension at $2500 \times g$ for $10 \mathrm{~min}$ and re-suspending the pellet in $200 \mu \mathrm{L}$ of STC buffer.

\section{Stability and PCR validation of the transformants}

TB3 medium (15 mL) containing $0.7 \%$ low meltingpoint agarose and $300 \mu \mathrm{g} \mathrm{mL} \mathrm{m}^{-1}$ of hygromycin B were thoroughly mixed with $200 \mu \mathrm{L}$ of fungal suspension and poured into a Petri dish. After incubation at $26{ }^{\circ} \mathrm{C}$ in the dark for 1 day, $10 \mathrm{~mL}$ of fresh hygromycin B-containing medium was poured on the surface of the original one. The colonies that emerged on the upper layer were picked up after 5-7 days of culture and transferred to PDA plates containing $300 \mu \mathrm{g} \mathrm{mL} \mathrm{m}^{-1}$ of hygromycin B three times in succession. The transformants that were able to grow on resistant plates were considered genetically stable. The colony number of the transformed protoplasts on TB3 plates was counted and the transformation efficiency was calculated.

PCR amplification of $h p h$ was conducted to verify the transformants. Total RNAs of the isolates were extracted using Trizol reagent (Invitrogen, Carlsbad, USA) according to the manufacturer's instruction, and cDNAs were synthesized using a cDNA Synthesis Kit (Takara, Dalian, China), from which $h p h$ fragments were amplified with $10 \mu \mathrm{M}$ primers $h p h \mathrm{~F}$ and $h p h \mathrm{R}$ (Table 1 ). The following PCR protocol was used: $95{ }^{\circ} \mathrm{C}$ for $5 \mathrm{~min}$; 30 cycles of $95{ }^{\circ} \mathrm{C}$ for $30 \mathrm{~s}, 55^{\circ} \mathrm{C}$ for $30 \mathrm{~s}$, and $72{ }^{\circ} \mathrm{C}$ for $1 \mathrm{~min}$; and an extension step at $72{ }^{\circ} \mathrm{C}$ for $10 \mathrm{~min}$.

\section{Growth and sporulation of transformants}

A total of 68 transformants were selected randomly for biological assays. A $0.5 \mathrm{~cm}$ diameter agar block of the transformants was placed on the center of a PDA medium-containing $9 \mathrm{~cm}$ Petri dish and incubated at $26^{\circ} \mathrm{C}$ in the dark. The colony morphology of the mutants was observed after 1 week of culture.

Simultaneously, a fungal block was placed on the surface of a PDA plate covered with a piece of sterile cellophane. After incubation for 1 week, the colony diameter and fresh weight together with the cellophane were measured. The spores were eluted from the fungal mycelia by sterile distilled water and the spores were counted under a microscope (BX41, Olympus, Tokyo, Japan). Three replicates were carried out for each transformant.

\section{Mycoparasitism against S. sclerotiorum sclerotia}

Sclerotia of S. sclerotiorum were prepared in carrot medium (Zhang et al. 2013), surface sterilized with $1 \%$ $\mathrm{NaClO}$ for $3 \mathrm{~min}$, and rinsed with sterile distilled water. Excess water was removed using sterile filter paper, and sclerotia were immersed into $C$. rosea suspension containing $1 \times 10^{7}$ spores $\mathrm{mL}^{-1}$. After $10 \mathrm{~min}$, sclerotia were retrieved, dried in the shade, and incubated on a piece of wet sterile filter paper in a Petri dish at $26^{\circ} \mathrm{C}$. The number of sclerotia infected by $C$. rosea was counted under a stereo microscope (SMZ-10, Nikon, Tokyo, Japan) at 8, 16 , and $20 \mathrm{~h}$, respectively, sclerotia covered with $C$. rosea mycelia were considered parasitized. Parasitic rates of the transformants were calculated, and severity of infection was recorded at $72 \mathrm{~h}$. Sclerotia immersed in sterile distilled water and the spore suspension of the wild type $C$. rosea 67-1 served as controls. A total of 30 sclerotia were tested for each transformant, and three replicates were used. 


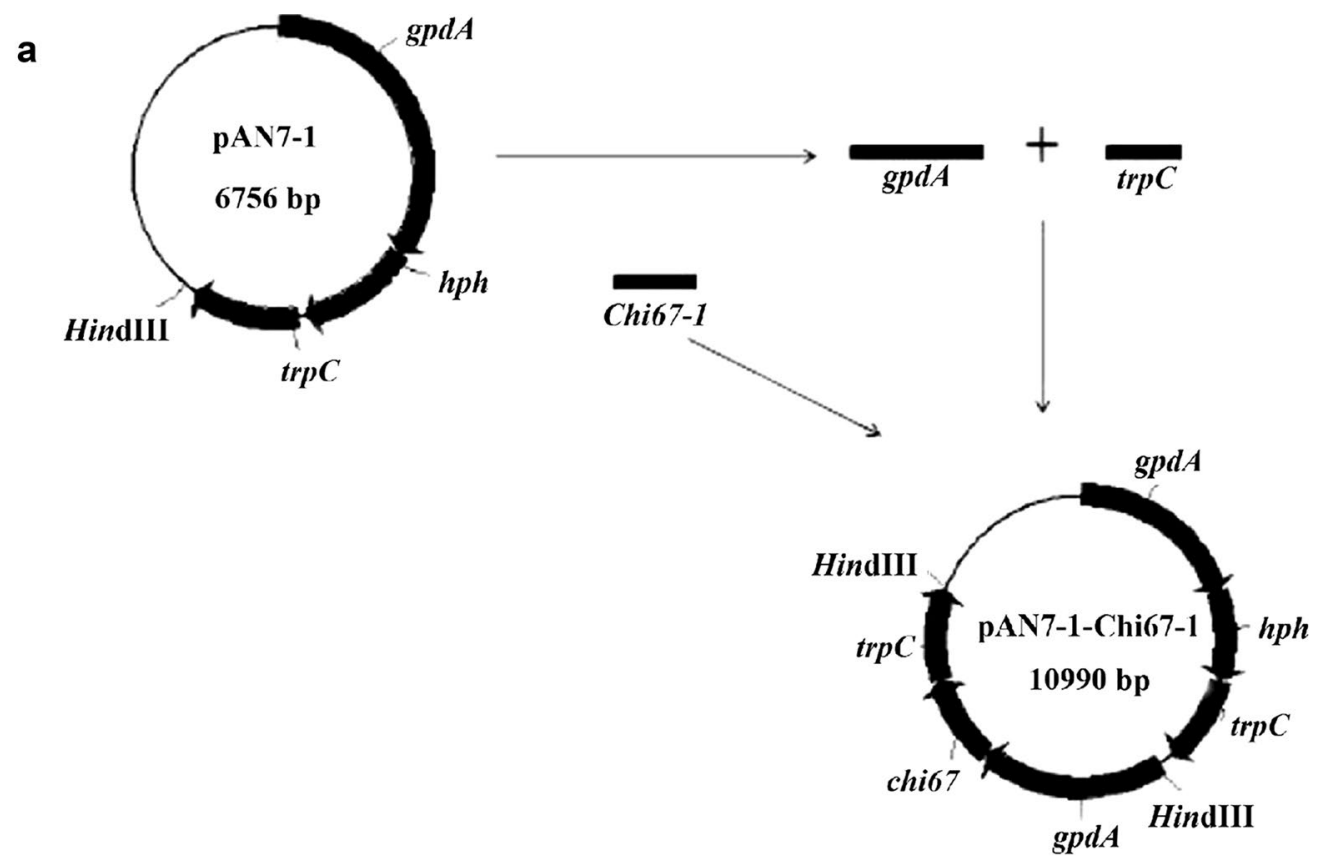

b
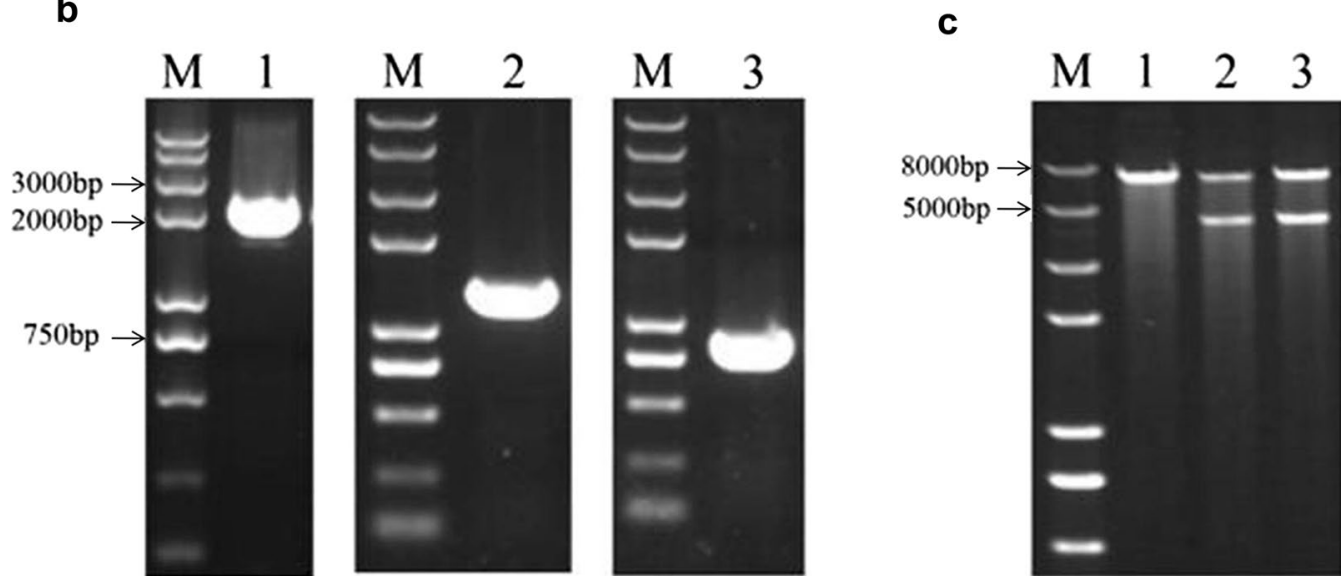

Fig. 1 Construction of the transformation vector pAN7-1-Chi67-1. a gpdA and trpC fragments, which were cloned from plasmid pAN7-1, and the Chi67-1 fragment cloned from the C. rosea strain 67-1 genome were ligated to the linearized pAN7-1, which was digested with HindIII to construct the transformation vector pAN7-1-Chi67-1. b PCR amplification of inserted fragments. M DNA marker; 1 gpdA; 2 Chi67-1; 3 trpC. c verification of transformation vector. 1 PAN7-1; 2, 3: constructed vector pAN7-1-Chi67-1

\section{Chitinase activity}

Highly parasitic transformants were selected for subsequent assays. The 67-1 isolate and its transformants were inoculated into PD broth containing $1 \%$ sclerotia powder and cultivated at $28{ }^{\circ} \mathrm{C}$ in a rotary shaker at $180 \mathrm{rpm}$ for 4 days. The fermentation liquor was centrifuged at $4{ }^{\circ} \mathrm{C}$ for $20 \mathrm{~min}$ at $3500 \times \mathrm{g}$, and crude enzymes were prepared. A standard curve was generated using $\mathrm{N}$-acetylglucosamine as a standard, and the chitinase activity of the transformants was determined (Reissig et al. 1995).

\section{Expression of Chi67-1 in the transformants}

The level of transcription of Chi67-1 in the transformants was assayed using an IQ5 Multicolor Real-Time PCR Detection System (Bio-Rad, CA, USA) and SYBR Premix Ex Taq (Takara, Dalian, China), with the elongation factor $E F 1$ as a reference gene (Sun et al. 2015a). Primers $C h i \mathrm{~F}$ and $C h i \mathrm{R}$ were designed and synthesized (Table 1), and the specificity was verified by using PCR amplification and sequencing. $10 \mu \mathrm{M}$ of each primer was used for real-time PCR with the following program: $95^{\circ} \mathrm{C}$ 
for $30 \mathrm{~s}$, followed by 40 cycles of $95{ }^{\circ} \mathrm{C}$ for $5 \mathrm{~s}$ and $55^{\circ} \mathrm{C}$ for $30 \mathrm{~s}$. After PCR, fluorescence values were collected every $0.5^{\circ} \mathrm{C}$ from 55 to $95^{\circ} \mathrm{C}$, and the relative expression level of Chi67-1 was calculated using the $2^{-\Delta \Delta C t}$ method (Livak and Schmittgen 2001). Three replicates were performed for each transformant.

\section{Control efficacy against soybean Sclerotinia stem rot}

Seven transformants with the highest rates of parasitism were selected for evaluation of their ability to control $S$. sclerotiorum on soybean in greenhouse experiments. Soil was collected from an experimental field in the Institute of Plant Protection, Chinese Academy of Agricultural Sciences (CAAS), mixed thoroughly with $20 \%$ nursery substrate, and placed in $11 \mathrm{~cm}$ plastic pots. A soybean seedling (cultivar Zigongdongdou, Institute of Crop Sciences of CAAS, China) was planted in each pot and watered every other day. When six compound leaves were grown, the plants were sprayed with $100 \mathrm{~mL}$ of spore suspension of the transformants with a concentration of $5 \times 10^{6}$ spores $\mathrm{mL}^{-1}$. After $2 \mathrm{~h}$, leaves were inoculated with an equal volume of $S$. sclerotiorum mycelial suspension. Seedlings treated with the wild type strain followed by the pathogen served as controls, and seedlings treated with the pesticide carbendazim $(1000 \times$ dilution) were simultaneously assayed. 12 pots were tested for each isolate, and all leaflets on each seedling were determined. Disease severity was recorded using a 9-grade scoring system based on the area of lesions on soybean leaves as follows: 0 , no symptoms; $1,<5 \% ; 3,5-10 \% ; 5,11-25 \%$; 7, 26-50\%; 9, >50\%. After 7 days, the disease index was calculated using the formula: disease index $=[\Sigma$ (number of infected leaves $\times$ disease grade)/(total number of leaves $\times$ the highest disease grade) $] \times 100$, and the control efficiency of each treatment was evaluated. Three replicates were performed for each sample.

\section{Statistical analysis}

The statistical software SAS 9.1.3 (SAS Institute Inc., Cary, NC, USA) was used for the analysis of variance (ANOVA). Fisher's LSD test was used to compare the means of fungal growth and sporulation, and Duncan's multiple range test was used to compare the means of biocontrol activities and gene expression levels. A $P$ value $<0.05$ was considered significant.

\section{Results}

\section{Construction of pAN7-1-Chi67-1}

The target fragments of gpdA (2097 bp), Chi67-1 (1307 bp), and $\operatorname{trpC}(770 \mathrm{bp})$ were successfully detected by electrophoresis (Fig. 1b). Recombinant plasmid pAN71-Chi67-1 was digested with HindIII and verified by electrophoresis, and two bands of the expected size were observed (Fig. 1c). Results of the sequencing indicated successful construction of the recombinant plasmid.

\section{Screening and biological characterization of transformants} The Chi67-1 gene was transferred into C. rosea 67-1 with an efficiency of approximately 50 transformants per $1 \times 10^{7}$ protoplasts. A total of 68 transformants that grew stably on hygromycin-containing plates were verified by PCR amplification of a specific fragment of $h p h$, indicating that pAN7-1-Chi67-1 had successfully integrated into the 67-1 strain.

Morphological observation revealed that the colonies of all the transformants and the wild type strain were similar. Of the 68 transformants tested, the largest extension diameter of a colony was $69.5 \pm 2.8 \mathrm{~mm}$ in 7 days, while the smallest was $61.2 \pm 2.2 \mathrm{~mm}(\mathrm{LSD}=3.4$, $P<0.05)$. The colony diameter of 30 transformants was larger than that of the wild strain $(63.7 \pm 2.7 \mathrm{~mm})$. Sporulation of transformants ranged from $(5.3 \pm 0.2) \times 10^{7}$ to $(57.2 \pm 1.6) \times 10^{7}$ spores plate ${ }^{-1}\left(\mathrm{LSD}=2.3 \times 10^{7}\right.$, $P<0.05)$, and more than a third of the mutants exhibited an increased sporulation ability compared with the wild type $\left(17.1 \times 10^{7}\right.$ spores plate $\left.^{-1}\right)$.

\section{Mycoparasitism of transformants against S. sclerotiorum sclerotia}

No hyphae were observed on the surface of the sclerotia at $8 \mathrm{~h}$ after inoculation with the wild strain. However, hyphae were visible in some sclerotia inoculated with transformants. For example, Rc5-1 and Rc5-7 treated sclerotia showed mycoparasite hyphae beginning to extend outwards, and by $16 \mathrm{~h}$, mycoparasitism was evident on all sclerotia infected with transformants and the wild type strain, but the parasitic ability of mutants was clearly higher than the wild type $(P<0.05)$. The parasitic rates of nearly a third of the transformants increased by $50 \%$, compared to $43.3 \%$ for isolate 67-1 (Table 2). Furthermore, there was a significant increase in mycoparasitism over time, and transformants produced considerably more hyphae that eventually covered the whole sclerotia surface, and infected sclerotia were demonstrably softer and rotten at $72 \mathrm{~h}$ (Fig. 2a).

\section{Chitinase activity}

A standard curve of chitinase activity was generated using the regression equation $y=0.0038 x+0.0304$, with a correlation coefficient $\left(R^{2}\right)$ of 0.9919 . The chitinase activity of transformants was calculated and ranged from 124.1 to $308.8 \mathrm{U} \mathrm{mL}^{-1}$. Most of the transformants displayed a higher chitinase activity than the wild strain, and activity was highest for transformant Rc4-4, which was 2.4-fold higher than that of the wild type (Table 3). 
Table 2 Parasitic rate of Chi67-1 transformants of C. rosea 67-1 against sclerotia of $S$. sclerotiorum

\begin{tabular}{llcc}
\hline Strain & $\mathbf{8} \mathbf{h}(\mathbf{\%})$ & $\mathbf{1 6} \mathbf{h}(\mathbf{\%})$ & $\mathbf{2 0} \mathbf{h}(\mathbf{\%})$ \\
\hline CK & $0.0^{\mathrm{b}}$ & $0.0^{\mathrm{h}}$ & $0.0^{\mathrm{c}}$ \\
Rc1-1 & $0.0^{\mathrm{b}}$ & $76.7^{\mathrm{bcd}}$ & $93.3^{\mathrm{ab}}$ \\
Rc2-8 & $0.0^{\mathrm{b}}$ & $66.7^{\mathrm{cde}}$ & $93.3^{\mathrm{ab}}$ \\
Rc2-10 & $0.0^{\mathrm{b}}$ & $60.0^{\mathrm{def}}$ & $90.0^{\mathrm{ab}}$ \\
Rc3-5 & $0.0^{\mathrm{b}}$ & $59.3^{\mathrm{def}}$ & $88.9^{\mathrm{ab}}$ \\
Rc3-7 & $0.0^{\mathrm{b}}$ & $53.3^{\mathrm{ef}}$ & $90.0^{\mathrm{ab}}$ \\
RC4-4 & $0.0^{\mathrm{b}}$ & $100.0^{\mathrm{a}}$ & $100.0^{\mathrm{a}}$ \\
RC4-5 & $0.0^{\mathrm{b}}$ & $83.3^{\mathrm{abc}}$ & $100.0^{\mathrm{a}}$ \\
RC4-7 & $0.0^{\mathrm{b}}$ & $86.2^{\mathrm{ab}}$ & $93.3^{\mathrm{ab}}$ \\
RC5-7 & $3.33^{\mathrm{a}}$ & $50.0^{\mathrm{ef}}$ & $90.0^{\mathrm{ab}}$ \\
RC8-5 & $0.0^{\mathrm{b}}$ & $30.0^{\mathrm{g}}$ & $90.0^{\mathrm{ab}}$ \\
WT & $0.0^{\mathrm{b}}$ & $43.3^{\mathrm{gf}}$ & $83.3^{\mathrm{b}}$ \\
\hline
\end{tabular}

Data are means of three replicates. Values within a column followed by different letters are significantly different at $P<0.05$ according to Duncan's multiple range test

WT wild type, CK distilled water

\section{Transcription level of Chi67-1 in the transformants}

The expression of Chi67-1 in transformants was increased significantly compared with the wild type strain $(P<0.05)$. Consistent with the result of chitinase activity measurement described above, expression of Chi67-1 was highest in transformant Rc4-4, which was 107-fold higher than the wild type (Fig. 3).

\section{Control efficacy of $C$. rosea transformants against soybean Sclerotinia stem rot in greenhouse}

Soybean leaves exhibited serious infection after incubation with the pathogen for 7 days. However, soybean seedlings treated with both the biocontrol fungi and pesticide were much healthier and exhibited less damage than the control. Consistent with the results of the Chi67-1 expression and chitinase activity measurement described above, the Rc4-4 transformant exhibited the highest control efficiency against soybean Sclerotinia stem rot (81.4\%), which was 31.7 and $28.7 \%$ higher than seedlings treated with the wild type strain and carbendazim, respectively (Table 4; Fig. 2b). Therefore, transformant Rc4-4 can be considered an efficient agent for controlling Sclerotinia rot of soybean.

\section{Discussion}

Biological methods have great potential for controlling plant fungal diseases. In 2015, China proposed a "tworeduction" strategy, i.e. reducing the application of chemical fertilizers and pesticides, which aims to fight against pollution problem in agriculture and improve food safety in China. Biocontrol agents are becoming increasingly important in achieving these goals while simultaneously

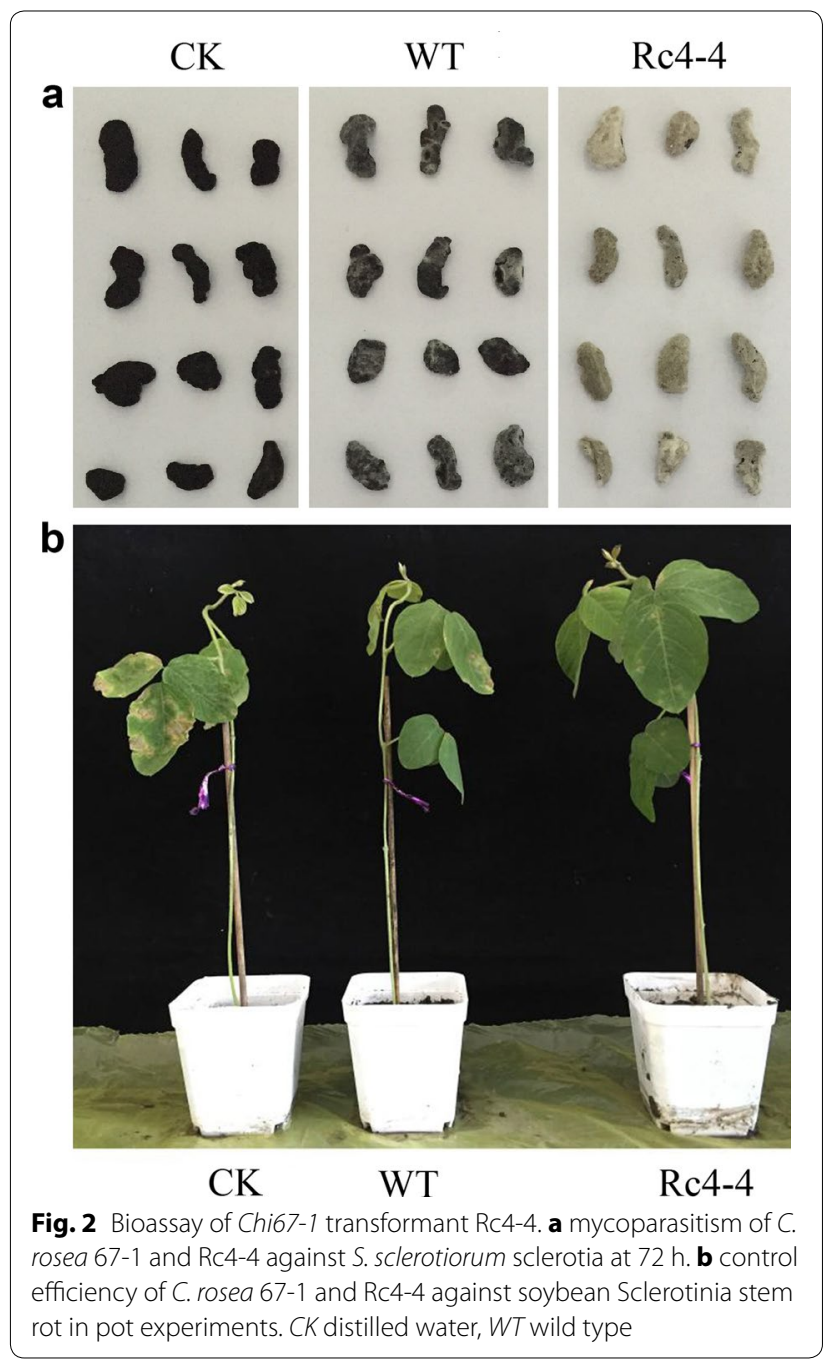

Table 3 Chitinase activity of Chi67-1 transformants of $C$. rosea 67-1

\begin{tabular}{ll}
\hline Strain & Enzyme activities $\left.\mathbf{(} \mathbf{~} \mathbf{~ L}^{-\mathbf{1}}\right)$ \\
\hline Rc1-1 & $124.1^{\mathrm{f}}$ \\
Rc2-8 & $150.5^{\mathrm{de}}$ \\
Rc2-10 & $125.1^{\mathrm{f}}$ \\
Rc3-5 & $257.9^{\mathrm{b}}$ \\
Rc3-7 & $169.2^{\mathrm{cd}}$ \\
Rc4-4 & $308.8^{\mathrm{a}}$ \\
Rc4-5 & $179.5^{\mathrm{c}}$ \\
Rc4-7 & $181.9^{\mathrm{c}}$ \\
Rc5-7 & $145.6^{\mathrm{ef}}$ \\
Rc8-5 & $171.2^{\mathrm{cd}}$ \\
WT & $129.3^{\mathrm{ef}}$ \\
\hline
\end{tabular}

Data are means of three replicates. Values within a column followed by different letters are significantly different at $P<0.05$ according to Duncan's multiple range test

WT wild type 


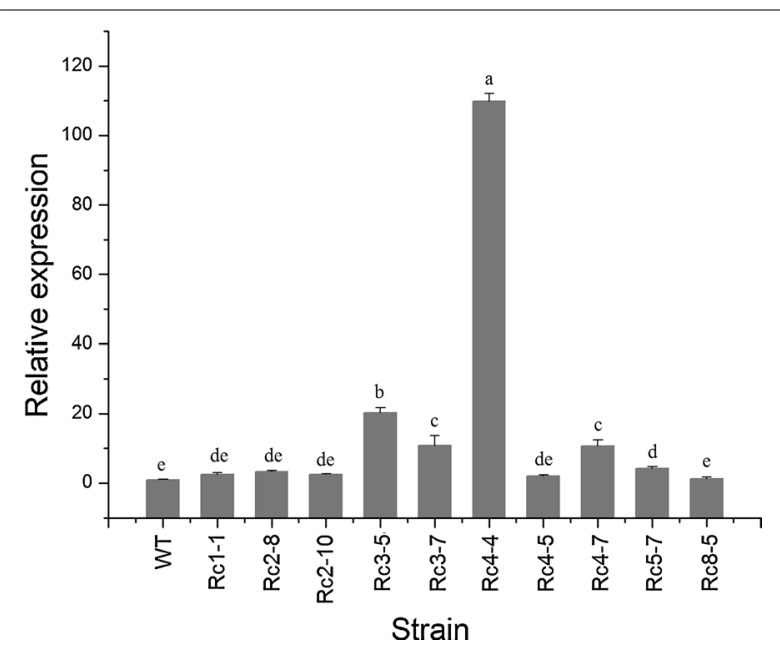

Fig. 3 Expression levels of Chi67-1 from C. rosea 67-1 and its transformants assessed using quantitative real-time PCR. WT wild type. Error bars indicate the standard deviations of three replicates. Different letters indicate significant differences $(P<0.05)$ according to Duncan's multiple range test

Table 4 Control efficacy of the Chi67-1 transformants of $C$. rosea 67-1 against soybean Sclerotinia stem rot in pots (7 days)

\begin{tabular}{lll}
\hline Strain & Disease index & Control efficacy (\%) \\
\hline Rc1-1 & $24.4^{\mathrm{b}}$ & $67.7^{\mathrm{b}}$ \\
Rc2-8 & $27.4^{\mathrm{b}}$ & $63.7^{\mathrm{b}}$ \\
Rc2-10 & $26.7^{\mathrm{b}}$ & $64.7^{\mathrm{b}}$ \\
Rc3-7 & $31.1^{\mathrm{b}}$ & $58.8^{\mathrm{b}}$ \\
Rc4-4 & $14.1^{\mathrm{c}}$ & $81.4^{\mathrm{a}}$ \\
Rc4-5 & $22.2^{\mathrm{bc}}$ & $70.6^{\mathrm{ab}}$ \\
Rc4-7 & $25.2^{\mathrm{b}}$ & $66.7^{\mathrm{b}}$ \\
Carbendazim & $27.8^{\mathrm{b}}$ & $63.2^{\mathrm{b}}$ \\
WT & $28.9^{\mathrm{b}}$ & $61.8^{\mathrm{b}}$ \\
CK & $74.8^{\mathrm{a}}$ & - \\
\hline
\end{tabular}

Data are means of three replicates. Values within a column followed by different letters are significantly different at $P<0.05$ according to Duncan's multiple range test

WT wild type, CK distilled water

enhancing crop production. However, some problems such as relatively low efficiency and instability of biopesticides have limited their development so far (Kredics et al. 2003; Slusarski and Pietr 2009). More biocontrol agents with high efficiency will be obtained with genetic improvement. In this study, we overexpressed the endochitinase-encoding gene Chi67-1 in the biocontrol fungus C. rosea 67-1 through protoplast transformation, selected several transformed strains with increased Chi67-1 expression, chitinase production and parasitic ability, and evaluated their ability to protect against
Sclerotinia rot of soybean in greenhouse experiments. Of the transformants screened in this study, Rc4-4 was found to exhibit a similar colony morphology, growth rate and sporulation ability as the wild strain, but this strain displayed a much higher capacity to control Sclerotinia rot of soybean. To the best of our knowledge, this is the first study to report the construction of a genetically engineered strain of $C$. rosea overexpressing an antifungal chitinase gene in order to enhance the biological control activity.

In a previous study, the endochitinase-encoding gene Chi67-1 was found to be significantly upregulated in $C$. rosea 67-1 parasitizing S. sclerotiorum, compared with expression in 67-1 not exposed to S. sclerotiorum (Sun et al. 2015b). Therefore, we decided to attempt to genetically engineer a highly efficient biocontrol strain by overexpressing this gene. The strategy and the result were similar to that seen in another study in which overexpression of the chitinase-encoding gene chit33 from $T$. harzianum CECT 2413 led to an increased inhibition of the growth of $R$. solani (Limón et al. 1999). Importantly, Chi67-1, which encodes a high-quality cell wall-degrading enzyme, can also be mass produced and utilized in the management of plant fungal diseases.

In vitro assays showed that most transformants exhibited a higher parasitic ability against sclerotia compared to the wild type strain. However, in pot experiments, only one transformant, Rc4-4, exhibited a much higher ability to control soybean Sclerotinia stem rot. This might be due to various antagonistic mechanisms other than a single pattern of mycoparasitism. The management of plant diseases with $C$. rosea involves several mechanisms such as mycoparasitism, antagonist action, induced resistance, and competition, which enhance the performance of the biocontrol fungus (Mouekouba et al. 2014; Zhang et al. 2008). In addition, colonization of the biocontrol isolates on plants during the growing season can also greatly affect the control efficiency (Vallance et al. 2009).

Of the 68 Chi67-1 transformants tested in this study, only a few obvious differences in colony morphology were observed. However, the transformants exhibited a wide variation in sporulation, ranging from 5.3 to $57.2 \times 10^{7}$ spores plate ${ }^{-1}$. This may be due to a random insertion of the recombinant plasmid that may have affected the sporulation pathway of the transformants and modified the expression of sporulation-related genes (Park et al. 2013; Yu et al. 2015). Since a high sporulation ability facilitates fungal mass production and commercialization, this may be a desirable feature in fungal strains to be used as biocontrol agents. Further studies should therefore be carried out to determine the safety of this $C$. rosea transformant and further assess its capacity to control soybean Sclerotinia stem rot. 


\section{Abbreviations}

Hph: hygromycin B-resistant gene; ORF: open reading frame; PDA: potato dextrose agar; PD: potato dextrose broth; CAAS: Chinese Academy of Agricultural Sciences; CK: control; WT: wild type.

\section{Authors' contributions}

SDL and MHS conceived and designed the experiments. ZBS and MZ performed the experiments. ZBS and MHS analyzed data and co-wrote the manuscript. All authors read and approved the final manuscript.

\section{Acknowledgements}

We thank Dr. X. Z. Liu (Institute of Microbiology, Chinese Academy of Sciences) for kindly providing the plasmid of pAN7-1.

\section{Competing interests}

The authors declare that they have no competing interests.

\section{Availability of data and materials}

Strains used in this study are available from the Agricultural Culture Collection of China (ACCC).

\section{Ethical approval}

This article does not contain any studies with human participants or animals performed by any of the authors.

\section{Funding}

This research was supported by the Program of Modern Agricultural Industry Technology System (CARS-25-B-02) and the Special Scientific Research Task of Chinese Ministry of Agriculture (201503112).

Received: 15 November 2016 Accepted: 19 December 2016 Published online: 03 January 2017

\section{References}

Carsolio C, Gutiérrez A, Jimenez B, Montagu M, Herrera-Estrella A (1994) Characterization of ech-42, a Trichoderma harzianum endochitinase gene expressed during mycoparasitism. Proc Natl Acad Sci USA 91:10903-10907

Carsolio C, Benhamou N, Haran S, Cortés C, Gutiérrez A, Chet I, Herrera-Estrella A (1999) Role of the Trichoderma harzianum endochitinase gene ech42 in mycoparasitism. Appl Environ Microbiol 65:29-935

Chatterton S, Punja ZK (2009) Chitinase and $\beta$-1,3-glucanase enzyme production by the mycoparasite Clonostachys rosea f. catenulata against fungal plant pathogens. Can J Microbiol 55:356-367

Cota LV, Maffia LA, Mizubuti ESG, Macedo PEF, Antunes RF (2008) Biological control of strawberry gray mold by Clonostachys rosea under field conditions. Biol Control 46:515-522

Deng SP, Lorito M, Penttilä M, Harman GE (2007) Overexpression of an endochitinase gene (ThEn-42) in Trichoderma atroviride for increased production of antifungal enzymes and enhanced antagonist action against pathogenic fungi. Appl Biochem Biotechnol 142:81-94

Elad Y, Kapat A (1999) The role of Trichoderma harzianum protease in the biocontrol of Botrytis cinerea. Eur J Plant Pathol 105:177-189

Gan ZW, Yang JK, Tao N, Yu ZF, Zhang KQ (2007) Cloning and expression analysis of a chitinase gene Crchil from the mycoparasitic fungus Clonostachys rosea (syn. Gliocladium roseum). J Microbiol 45:422-430

Giczey G, Kerényi Z, Fülöp L, Hornok L (2001) Expression of cmg1, an exo1,3-glucanase gene from Coniothyrium minitans, increases during sclerotial parasitism. Appl Environ Microbiol 67:865-871

Gwynn RL (2014) The manual of biocontrol agents, 5th edn. BCPC Publication, Hampshire

Haran S, Schickler H, Logemann S, Oppenheim A, Chet I (1993) Increased constitutive chitinase activity in transformed Trichoderma harzianum. Biol Control 3:101-108

Keyser CA, Jensen B, Meyling NV (2016) Dual effects of Metarhizium spp. and Clonostachys rosea against an insect and a seed-borne pathogen in wheat. Pest Manag Sci 72:517-526
Kredics L, Antal Z, Manczinger L, Szekeres A, Kevei F, Nagy E (2003) Influence of environmental parameters on Trichoderma strains with biocontrol potential. Food Technol Biotechnol 41:37-42

Lahoz E, Contillo R, Porrone F (2004) Induction of systemic resistance to Erysiphe orontii Cast in tobacco by application on roots of an isolate of Gliocladium roseum bainier. J Phytopathol 152:465-470

Limón MC, Pintor-Toro JA, Benítez T (1999) Increased antifungal activity of Trichoderma harzianum transformants that overexpress a $33 \mathrm{kDa}$ chitinase. Phytopathology 89:254-261

Livak KJ, Schmittgen TD (2001) Analysis of relative gene expression data using real-time quantitative $P C R$ and the $2^{-\Delta \Delta C t}$ method. Methods 25:402-408

Lorito M, Woo SL, Fernandez IG, Colucci G, Harman GE, Pintor-Toro JA, Filippone E, Muccifora S, Lawrence CB, Zoina A, Tuzun S, Scala F (1998) Genes from mycoparasitic fungi as a source for improving plant resistance to fungal pathogens. Proc Natl Acad Sci USA 95:7860-7865

Ma GZ, Wang SF, Bao ZH, Li SD, Sun MH, Fu HR, Ge PH (2011) Inhibition and protective activities of Gliocladium roseum 67-1 to Rhizoctonia solani. Crops 6:77-80

Mamarabadi M, Jensen B, Lcobeck M (2008) Three endochitinase-encoding genes identified in the biocontrol fungus Clonostachys rosea are differentially expressed. Curr Genet 54:57-70

Margolles-Clark E, Hayes CK, Harman GE, Penttilä M (1996) Improved production of Trichoderma harzianum endochitinase by expression in Trichoderma reesei. Appl Environ Microbiol 62:2145-2151

Morandi MAB, Maffia LA, Mizubuti ESG, Alfenas AC, Barbosa JG (2003) Suppression of Botrytis cinerea sporulation by Clonostachys rosea on rose debris: a valuable component in Botrytis blight management in commercial greenhouses. Biol Control 26:311-317

Mouekouba LD, Zhang L, Guan X, Chen X, Chen H, Zhang J, Zhang J, Li J, Yang Y, Wang A (2014) Analysis of Clonostachys rosea-induced resistance to tomato gray mold disease in tomato leaves. PLoS ONE 9:e102690

Papavizas GC (1985) Trichoderma and Gliocladium: biology, ecology, and potential for biocontrol. Annu Rev Phytopathol 23:23-54

Park SY, Jeong MH, Wang HY, Kim JA, Yu NH, Kim S, Cheong YH, Kang S, Lee YH, Hur JS (2013) Agrobacterium tumefaciens-mediated transformation of the lichen fungus, Umbilicaria muehlenbergii. PLOS ONE 8:e83896

Punja ZK, Yip R (2003) Biological control of damping-off and root rot caused by Pythium aphanidermatum on greenhouse cucumbers. Can J Plant Pathol 25:411-417

Rahman M, Punja ZK (2007) Biological control of damping-off on American ginseng (Panax quinquefolius) by Clonostachys rosea f. catenulate (=Gliocladium catenulatum). Can J Plant Pathol 29:203-207

Reissig JL, Strominger JL, Leloir LF (1995) A modified colorimetric method for the estimation of $\mathrm{N}$-acetylamino sugars. Biol Chem 217:956-966

Rodríguez MA, Cabrera G, Gozzo FC, Eberlin MN, Godeas A (2011) Clonostachys rosea BAFC3874 as a Sclerotinia sclerotiorum antagonist: mechanisms involved and potential as a biocontrol agent. J Appl Microbiol 110:1177-1186

Romao-Dumaresq AS, de Araujo WL, Talbot NJ, Thornton CR (2012) RNA interference of endochitinases in the sugarcane endophyte Trichoderma virens 223 reduces its fitness as a biocontrol agent of pineapple disease. PLOS ONE 7:e47888

Schöneberg A, Musa T, Voegele RT, Vogelgsang S (2015) The potential of antagonistic fungi for control of Fusarium graminearum and Fusarium crookwellense varies depending on the experimental approach. J Appl Microbiol 118:1165-1179

Seidl V, Huemer B, Seiboth B, Kubicek CP (2005) A complete survey of Trichoderma chitinases reveals three distinct subgroups of family 18 chitinases. FEBS J 272:5923-5939

Slusarski C, Pietr SJ (2009) Combined application of dazomet and Trichoderma asperellum as an efficient alternative to methyl bromide in controlling the soilborne disease complex of bell pepper. Crop Prot 28:668-674

Sun ZB, Li SD, Sun MH (2015a) Selection of reliable reference genes for gene expression studies in Clonostachys rosea 67-1 under sclerotial induction. J Microbiol Methods 114:62-65

Sun ZB, Sun MH, Li SD (2015b) Identification of mycoparasitism-related genes in Clonostachys rosea 67-1 active against Sclerotinia sclerotiorum. Sci Rep 14:18169

Sun ZB, Sun MH, Li SD (2015c) Draft genome sequence of mycoparasite Clonostachys rosea strain 67-1. Genome Announc 3(3):e00546-e00615 
Tzelepis G, Dubey M, Jensen DF, Karlsson M (2015) Identifying glycoside hydrolase family 18 genes in the mycoparasitic fungal species Clonostachys rosea. Microbiology 161:1407-1419

Vallance J, Le Floch G, Déniel F, Barbier G, Lévesque CA, Rey P (2009) Influence of Pythium oligandrum biocontrol on fungal and oomycete population dynamics in the rhizosphere. Appl Environ Microbiol 75:4790-4800

Woo SL, Donzelli B, Scala F, Mach R, Harman GE, Kubicek CP, Del Sorbo G, Lorito M (1999) Disruption of the ech42 (endochitinase-encoding) gene affects biocontrol activity in Trichoderma harzianum P1. Mol Plant Microbe Interact 12:419-429

Yang LM, Yang Q, Sun KN, Tian Y, Li HL (2011) Agrobacterium tumefaciens mediated transformation of ChiV gene to Trichoderma harzianum. Appl Biochem Biotechnol 163:937-945

Yu M, Yu J, Hu J, Huang L, Wang Y, Yin X, Nie Y, Meng X, Wang W, Liu Y (2015) Identification of pathogenicity-related genes in the rice pathogen Ustilaginoidea virens through random insertional mutagenesis. Fungal Genet Biol 76:10-19
Zeilinger S, Galhaup C, Payer K, Woo SL, Mach RL, Fekete C, Lorito M, Kubicek CP (1999) Chitinase gene expression during mycoparasitic interaction of Trichoderma harzianum with its host. Fungal Genet Biol 26:131-140

Zhang YH, Gao HL, Ma GZ, Li SD (2004) Mycoparasitism of Gliocladium roseum 67-1 on Sclerotinia sclerotiorum. Acta Phytopathol Sin 34:211-214

Zhang L, Yang J, Niu Q, Zhao X, Ye F, Liang L, Zhang KQ (2008) Investigation on the infection mechanism of the fungus Clonostachys rosea against nematodes using the green fluorescent protein. Appl Microbiol Biotechnol 78:983-990

Zhang Y, Sun MH, Li SD, Luo M (2013) Cloning and functional analysis of endoglucanase gene from Gliocladium catenulatum $\mathrm{HL}-1-1$. Chin J Biol Control 29:74-82

\section{Submit your manuscript to a SpringerOpen ${ }^{\circ}$ journal and benefit from:}

- Convenient online submission

- Rigorous peer review

- Immediate publication on acceptance

- Open access: articles freely available online

- High visibility within the field

- Retaining the copyright to your article 